University of Nebraska - Lincoln

DigitalCommons@University of Nebraska - Lincoln

$10-2002$

\title{
Disentangling Pay and Productivity in a Corporatist Economy: The Case of Germany
}

Scott M. Fuess Jr.

University of Nebraska-Lincoln, SFUESS1@UNL.EDU

Meghan Millea

Mississippi State University, mjm51@msstate.edu

Follow this and additional works at: https://digitalcommons.unl.edu/econfacpub

Part of the Economics Commons

Fuess, Scott M. Jr. and Millea, Meghan, "Disentangling Pay and Productivity in a Corporatist Economy: The Case of Germany" (2002). Economics Department Faculty Publications. 39.

https://digitalcommons.unl.edu/econfacpub/39

This Article is brought to you for free and open access by the Economics Department at DigitalCommons@University of Nebraska - Lincoln. It has been accepted for inclusion in Economics Department Faculty Publications by an authorized administrator of DigitalCommons@University of Nebraska - Lincoln. 


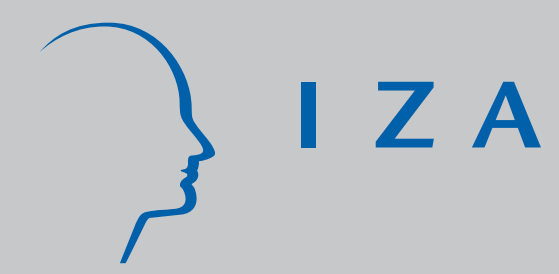

IZA DP No. 597

Disentangling Pay and Productivity in a Corporatist Economy: The Case of Germany

Scott M. Fuess, J r.

Meghan Millea

October 2002 


\title{
Disentangling Pay and Productivity in a Corporatist Economy: The Case of Germany
}

\author{
Scott M. Fuess, Jr. \\ University of Nebraska and IZA Bonn \\ Meghan Millea \\ Mississippi State University
}

Discussion Paper No. 597

October 2002

\author{
IZA \\ P.O. Box 7240 \\ D-53072 Bonn \\ Germany \\ Tel.: +49-228-3894-0 \\ Fax: +49-228-3894-210 \\ Email: iza@iza.org
}

This Discussion Paper is issued within the framework of IZA's research area The Future of Labor. Any opinions expressed here are those of the author(s) and not those of the institute. Research disseminated by IZA may include views on policy, but the institute itself takes no institutional policy positions.

The Institute for the Study of Labor (IZA) in Bonn is a local and virtual international research center and a place of communication between science, politics and business. IZA is an independent, nonprofit limited liability company (Gesellschaft mit beschränkter Haftung) supported by the Deutsche Post AG. The center is associated with the University of Bonn and offers a stimulating research environment through its research networks, research support, and visitors and doctoral programs. IZA engages in (i) original and internationally competitive research in all fields of labor economics, (ii) development of policy concepts, and (iii) dissemination of research results and concepts to the interested public. The current research program deals with (1) mobility and flexibility of labor, (2) internationalization of labor markets, (3) welfare state and labor market, (4) labor markets in transition countries, (5) the future of labor, (6) evaluation of labor market policies and projects and (7) general labor economics.

IZA Discussion Papers often represent preliminary work and are circulated to encourage discussion. Citation of such a paper should account for its provisional character. A revised version may be available on the IZA website (www.iza.org) or directly from the author. 
IZA Discussion Paper No. 597

October 2002

\section{ABSTRACT}

\section{Disentangling Pay and Productivity in a Corporatist Economy: The Case of Germany*}

Conventional theory predicts that productivity gains lead to pay hikes. Pay increases, however, can influence labor productivity. But what about in a corporatist economy? Focusing on Germany, we use an innovative technique developed by Geweke to disentangle the relationship between pay and productivity.

JEL Classification: J41, C22, J50, J30

Keywords: labor contracts, efficiency wages, corporatism

Corresponding author:

Scott M. Fuess, Jr.

Department of Economics

University of Nebraska

Lincoln, NE 68588-0489

USA

Tel.: $+1402-472-6281$

Fax: +1 402-472-9700

Email: sfuess1@unl.edu

\footnotetext{
* All econometric results (including those of diagnostic tests) are available from the authors. Likewise, technical details on the bias adjustment procedure and the construction of the confidence intervals are available on request.
} 


\section{Introduction}

Conventional theory predicts that productivity gains stimulate labor demand and drive up pay. On the other hand, following a wage hike firms may rely more on capital, which could boost output per worker. According to efficiency wage models, pay hikes can have a widespread impact on labor productivity by reducing turnover, boosting morale, or encouraging longterm employment (see the collection edited by Akerlof and Yellen, 1986). Productivity should drive pay; likewise pay can influence productivity. But what about in a corporatist economy?

Corporatism is usually characterized as labor-management coordination in wage setting, with industry- or economy-wide bargaining between union and employer federations. According to critics, labor pacts are driven not so much by market forces, but institutional considerations (see Olson, 1996). But it also has been argued that in a corporatist setting unions must account for the external effects of their demands, making wages flexible (Calmfors and Driffil, 1988).

As European markets become more integrated, some observers have questioned whether corporatism can survive there. To consider such a question, it is crucial to understand how pay and productivity are related. Are industry-wide pay pacts responsive to changes in productivity? Does corporatist consensus to boost pay help or hinder productivity? Such questions reflect an identification problem, whether productivity gains are the result or the source of higher pay. To overcome this problem we use a statistical method developed by Geweke $(1982,1984)$ to assess bi-directional causality between time series. For the case of Germany, a prominent corporatist country, we use the Geweke method to disentangle pay-productivity relationships.

\section{Collective Bargaining Structure in Germany}

In the words of Paqué (1993, p. 209), Germany's industrial relations are based on "tight corporatism." In an industry, collective agreements on wages and salaries are concluded between a labor union and an employer federation. Typically, a labor pact is for twelve months, with the annual bargaining round occurring in the first quarter of the year. Contract terms extend to nonunion workers, so nearly 90 percent of all employees work under the terms of union 
contracts. The metal industry is especially critical. It encompasses motor vehicles, engineering, and electronics, more than half of Germany's industrial employment. In this key sector, the $I G$ Metall union negotiates with the Gesamtmetall employers' association. Their contract settlements often set a standard for others to follow. ${ }^{1}$

Given the industry-wide consensus necessary to reach labor settlements, it is not obvious how responsive pay is to productivity gains. Cozy labor relations may make efforts to improve productivity seem less crucial. Or perhaps an accord to raise pay is a signal, stimulating labor's efforts or encouraging accumulation of more capital.

\section{Geweke Linear Feedback Method: Overview}

Geweke $(1982,1984)$ has developed measures of statistical feedback which also account for any interdependence between time series, thereby extending Granger's (1969) definition of causality. This method can be used to disentangle the direction and magnitude of the linear relationships between two time series, while controlling for any contemporaneous association. ${ }^{2}$

For the case of Germany, we apply Geweke's feedback technique to measure the extent to which adjustments in contractual pay have followed or led changes in productivity. The data distinguish between wages of blue-collar workers and salaries of white-collar employees. Therefore, we can assess how wage or salary settlements are related, if at all, to productivity.

Suppose there are two time-series vectors prd (productivity) and pay (pay specified in a labor contract). Geweke (1982) decomposes linear dependence between the series into three components: (1) feedback from prd to pay, (2) feedback from pay to prd, and (3) contemporaneous association between the series.

${ }^{1}$ For a particular geographic area of Germany (usually a federal state), a labor pact applies to all firms in an industry. There is some firm-level bargaining, but most pacts are industry-wide. See Berghahn and Karsten (1987) and Paqué (1993) for historical details.

${ }^{2}$ Focusing on Japan, which has its own unique brand of coordinated labor relations, Fuess and Millea (2002) used the Geweke method to evaluate wage setting in manufacturing. 
The interrelationship between pay and productivity is likely to differ according to labor market conditions. The basic feedback method described below can be extended to include what Geweke (1984) called conditioning information, that is, a control variable. Including such a variable allows us to decompose pay and prd, conditional on different states of the labor market.

Germany has experienced different labor market trends over the years. Between 1960 and 1972 its unemployment tended to hover around 1 percent, falling as low as 0.7 percent. Since 1972 it has been trending steadily upward, from 1.1 percent (1972) to 10.5 percent (1998).

Presumably, the responsiveness of pay to productivity improvements may vary as unemployment varies. Any efficiency consequences of pay changes are also likely to be different when unemployment is rising.

A conditional forecast of productivity at time $t\left(p r d_{t}\right)$ can be made using past values of productivity $\left(p r d_{t-s}\right)$, pay $\left(p a y_{t-s}\right)$, and unemployment $\left(u r_{t-s}\right)$ :

$$
\operatorname{prd}_{t}=\sum_{s=1} a_{1}(s) p r d_{t-s}+\sum_{s=1} a_{2}(s) \operatorname{pay}_{t-s}+\sum_{s=1} a_{3}(s) u r_{t-s}+\varepsilon_{1 t},
$$

where the $a$ 's are coefficient vectors and $\varepsilon_{1 \mathrm{t}}$ is the random prediction error with variance $\sigma^{2}{ }_{1}$.

To account for the marginal contribution of $\mathrm{pay}_{t-s}$ in the productivity forecast, we compare the $\operatorname{prd}_{t}$ forecast generated with the earnings series to a prediction created without the series. Thus, we modify equation (1) and estimate $p r d_{t}$ again:

$$
\operatorname{prd}_{t}=\sum_{s=1} b_{1}(s) p r d_{t-s}+\sum_{s=1} b_{2}(s) u r_{t-s}+\varepsilon_{2 t},
$$

where $\operatorname{var}\left(\varepsilon_{2 t}\right)=\sigma_{2}^{2}$. Conditional feedback from pay to productivity is defined as

$$
F_{p a y \rightarrow p r d \mid u r} \equiv \log \left(\sigma_{2}^{2} / \sigma_{1}^{2}\right) \text {. }
$$

If the two variances are the same, then $p a y_{t-s}$ values do not improve the precision of the productivity forecast, so $F_{\text {pay } \rightarrow \text { prdur }}=0$.

For conditional feedback from productivity to pay, we estimate the following equations:

$$
\begin{aligned}
& \text { pay }_{t}=\sum_{s=1} a_{4}(s) \text { pay }_{t-s}+\sum_{s=1} a_{5}(s) p r d_{t-s}+\sum_{s=1} a_{6}(s) u r_{t-s}+\varepsilon_{3 t}, \\
& \text { pay }_{t}=\sum_{s=1} b_{3}(s) p a y_{t-s}+\sum_{s=1} b_{4}(s) u r_{t-s}+\varepsilon_{4 t},
\end{aligned}
$$

where the prediction error variances are, respectively, $\sigma_{3}^{2}$ and $\sigma^{2}{ }_{4}$. Conditional feedback from 
productivity to pay is simply

$$
F_{p r d \rightarrow p a y \mid u r} \equiv \log \left(\sigma_{4}^{2} / \sigma^{2}{ }_{3}\right) .
$$

A distinguishing feature of the Geweke method is that it also accounts for any simultaneous association that cannot be disentangled. To identify this contemporaneous component, we modify the $\mathrm{prd}_{t}$ forecast by also including current pay:

$$
\operatorname{prd}_{t}=\sum_{s=1} c_{1}(s) \operatorname{prd}_{t-s}+\sum_{s=0} c_{2}(s) \operatorname{pay}_{t-s}+\sum_{s=1} c_{3}(s) u r_{t-s}+\mathcal{E}_{5 t},
$$

where $\operatorname{var}\left(\mathcal{E}_{5 t}\right)=\sigma^{2}$. Including current earnings may improve the forecast's precision. Thus, the measure of contemporaneous association is

$$
F_{\text {pay } \cdot \text { prdur }} \equiv \log \left(\sigma_{1}^{2} / \sigma_{5}^{2}\right) .
$$

If including current pay does not reduce the prediction error, then $\sigma^{2}{ }_{5}=\sigma^{2}{ }_{1}$ and $F_{p a y} \cdot p r d u r=0$, meaning there is no contemporaneous association between the series.

Given the different types of feedback, we can disentangle pay and productivity. The feedback measure $F_{\text {prd } \rightarrow \text { paylur }}$ indicates whether productivity leads employee earnings, which would be consistent with conventional labor demand. The measure $F_{p a y} \rightarrow$ prdur shows whether pay leads productivity, that is, whether there are efficiency consequences from pay adjustments. Finally, $F_{p a y} \cdot p r d u r$ shows the extent of simultaneity between pay and prd.

The feedback measures defined above can be transformed into growth rates using the formula $[1-\exp (-F)]$. For example, transforming $F_{p a y} \rightarrow$ prdlur shows the proportional reduction in the prediction error variance of $p r d_{t}$ that can be attributed to past values of $p a y_{t-s}$, conditional on unemployment. In other words, the transformation illustrates the capacity of past earnings to reduce the variance of prediction error in the productivity forecast.

\section{Disentangling Contractual Pay and Productivity in Germany}

\subsection{Implementing the Geweke Method}

The German Ministry of Labor publishes an index of the collectively bargained pay of wage earners in trade and industry (gewerbliche Wirtschaft). Likewise, there is an index for the collectively bargained pay of salary earners. The respective indices, available back to 1960 , 
reflect the level of contractual pay for blue-collar and white-collar employees in German industry (see appendix for data sources).

The German government also reports an index of labor productivity (real output per gainfully employed person), which is available through 1998 (see appendix). ${ }^{3}$ Using the unemployment rate for western Germany as the labor market conditioning variable, for 1960-1998 we can analyze the interrelationship between productivity and contractual wages (salaries). We determine if productivity changes in Germany have affected contractual wages or salaries. Perhaps contractual pay hikes are a signal, leading to more effective labor efforts. So we determine if pay changes have affected productivity.

In implementing the Geweke method, the forecast equations must be estimated with stationary time series, otherwise the forecasts may be subject to spurious correlation. One may wish to use productivity and pay levels to estimate the forecast equations. But using the PhillipsPerron (1988) unit root test, we cannot reject the null hypothesis of nonstationarity for the prd and pay series in levels. Their first-differences, however, are stationary. Thus, we used $p r d^{*}{ }_{t} \equiv$ $\left(\operatorname{prd}_{t}-\operatorname{prd}_{t-1}\right), p a y_{t}^{*} \equiv\left(p a y_{t}-p a y_{t-1}\right)$, which reflect changes in productivity and pay, respectively. Unemployment is not stationary in levels-form either, but $u r^{*}{ }_{t} \equiv\left(u r_{t}-u r_{t-1}\right)$ is stationary.

To obtain the $p r d^{*}{ }_{t}$ and $p a y^{*}{ }_{t}$ forecasts we used OLS regression. ${ }^{4}$ Then we computed the

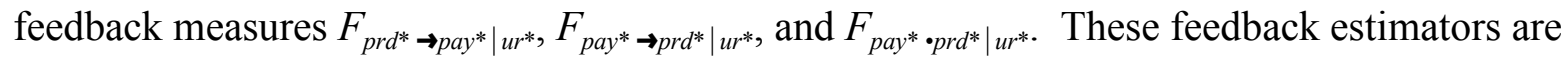
consistent, but because they are based on variances they are nonnegative by construction and potentially biased upward in small samples. Following the procedure developed by Cushing and McGarvey (1990), we adjusted the point estimates for small sample bias and then created 90-

${ }^{3}$ Our 1960-1998 sample period includes German reunification. To insure consistent series over time, all data used in this study are only for western Germany (Früheres Bundesgebiet).

${ }^{4}$ According to Akaike's information criterion, for the forecast equations the optimal lag length was one. 
percent confidence bands for each estimator. ${ }^{5}$ Using $[1-\exp (-F)]$, we transformed the adjusted feedback measures and associated confidence bands, which allows us to gauge the rate of change in the prediction error variance of a forecast.

\subsection{Conditional Feedback Results}

Table 1 presents conditional feedback measures, with results for wage earners in Panel A and those for salaried employees in Panel B. In one respect the findings are similar: there is little simultaneity between pay changes and productivity gains. The point estimates indicate virtually no contemporaneous association between $w g^{*}\left(s l^{*}\right)$ and $p r d^{*}$. There is, however, meaningful directional feedback between the series.

Consider the impact of productivity on pay. The conditional feedback measures indicate that changes in productivity lead changes in both contractual wages and salaries.

For wage earners (Panel A), the feedback point estimate shows that $\mathrm{prd}_{t-s}^{*}$ improves the $w{ }^{*}{ }_{t}$ forecast by 7.3 percent. According to the confidence interval, the improvement could be as great as 91.5 percent. The results are similar for salaried employees (Panel B). Looking at the point estimate, $p r d_{t-s}^{*}$ reduces the prediction error variance of the $s l^{*}{ }_{t}$ forecast by 8.3 percent. The confidence interval shows that the reduction may be as much as 72.9 percent.

Clearly, productivity changes lead to labor contracts that adjust both wages and salaries, confirming conventional labor demand behavior. ${ }^{6}$ Industry-wide collective bargaining notwithstanding, both contractual wage and salary setting in Germany are consistent with classical labor demand theory.

\footnotetext{
${ }^{5}$ The adjusted feedback point estimates do not have associated test statistics. Following the simulation process of Cushing and McGarvey (1990), we constructed bands to indicate the potential magnitude of the feedback measures.

${ }^{6}$ The conditional feedback measures show that $\mathrm{prd}^{*}{ }_{t-s}$ leads $w g^{*}{ }_{t}$ and $s l^{*}{ }_{t}$. Strictly speaking, they do not verify that the impacts are positive. Using the impulse response method developed by Sims (1980) - which is often used to trace out the reaction of one time series to an impulse in another series - we confirmed that an innovation in prd $^{*}$ leads to wage and salary increases.
} 
Turning to the impact of pay on productivity, there is a difference between types of employees. For blue-collar workers, changes in contractual wages have no effect whatsoever on productivity growth. The conditional feedback point estimate is 0 percent, with the high value of the confidence interval reaching a mere 0.8 percent.

Focusing on white-collar workers, the results are less clear cut. According to the point estimate, $s l_{t-s}^{*}$ has only a slight influence on the $p r d^{*}{ }_{t}$ forecast. But the 90 -percent confidence interval shows that $s l_{t-s}^{*}$ improves the $p r d^{*}{ }_{t}$ forecast by as much as 48.9 percent. Including $s l_{t-s}^{*}$ can reduce considerably the prediction error variance of the $\mathrm{prd}^{*}{ }_{t}$ forecast. Thus, there are efficiency consequences following salary growth: bigger salary hikes for white-collar workers can yield widespread improvements in productivity. ${ }^{7}$

Predictions of the demise of corporatism may be premature. Germany's corporatist pay setting has been responsive to market signals, with productivity gains stimulating wage and salary increases. Moreover, salary increases for managers and executives can lead to efficiency gains.

In an exhaustive study, Teulings and Hartog (1998) hypothesized that corporatism enhances the efficiency of nominal contracts, because it is easier to adjust pay to aggregate shocks. We find another possible efficiency benefit. Evidently pay can affect managerial performance, and thus, labor productivity. It remains to identify more precisely how the productivity improvements are achieved. Perhaps there is efficiency pay setting, with salary increases motivating managers and executives to work harder or monitor workers more closely. Or perhaps pay hikes lead managers to deploy factors of production more effectively. We would expect future research to examine in detail the particular incentive effects of white-collar pay, to identify the means by which salary adjustments stimulate productivity gains.

${ }^{7}$ With impulse response analysis (see Sims, 1980), we confirmed that an innovation in $s l^{*}$ leads immediately to bigger productivity gains. 


\section{Appendix}

Productivity. The index of real labor productivity is real output per gainfully employed person. Figures for productivity growth are reported in [2], 1998 edition, Table 36; 1992 edition, Table 40; see "Data References" below. Setting 1985 = 100, we constructed the index for 19601998.

Contractual Wages and Salaries. The index of collectively bargained (nominal) contract wages for wage earners (Index der Tariflöhne) employed in trade and industry or regional authorities is reported in [1], Table 5.1. Likewise, the index of collectively bargained salaries for salary earners (Index der Tarifgehälter) is reported in [1], Table 5.1.

To generate real values, we deflated each index using the GDP deflator for western Germany. Growth rates for the western German GDP deflator (base year, 1991) are reported in [2], 1998 edition, Table 36; 1992 edition, Table 40. With these growth rates, we constructed an index for the GDP deflator.

Unemployment. Unemployment rates for western Germany for 1960-1991 are reported in [1], Table 2.10; for 1991-1998 the rates are reported in [2], 1999 edition, Table 23. In Germany, the unemployment rate is defined as the number of unemployed persons as a percentage of gainfully employed persons.

Data References.

1. Bundesministerium für Arbeit und Sozialordnung. [BMA]. 2000. Statistisches Taschenbuch '99. Bonn: BMA [Translation: Federal Ministry for Labor and Social Affairs. Statistical Pocketbook '99. Bonn: BMA].

2. Institut der Deutschen Wirtschaft Köln. [IDWK]. 1999. 1998. 1992. Zahlen zur wirtschaftlichen Entwicklung der Bundesrepublik Deutschland. Ausgaben 1999, 1998, 1992. Köln: IDWK [Translation: Institute of the German Economy Cologne. Figures for the Economic Development of the Federal Republic of Germany. Editions for 1999, 1998, 1992. Cologne: IDWK]. 


\section{References}

Akerlof, G.A. and J.L. Yellen, eds., 1986. Efficiency wage models of the labor market (Cambridge University Press, Cambridge).

Berghahn, V.R. and D. Karsten, 1987. Industrial relations in West Germany (Berg, Oxford).

Calmfors, L. and J. Driffil, 1988. Bargaining structure, corporatism, and macroeconomic performance. Economic Policy 6, 14-61.

Cushing, M.J. and M.G. McGarvey, 1990. Feedback between wholesale and consumer price inflation: A reexamination of the evidence. Southern Economic Journal 56, 1059-1072.

Fuess, S.M. Jr. and M. Millea, 2002. Do employers pay efficiency wages? Evidence from Japan. Journal of Labor Research 23, 279-292.

Geweke, J., 1982. Measurement of linear dependence and feedback between multiple time series. Journal of the American Statistical Association 77, 304-313. , 1984. Measurement of conditional linear dependence and feedback between time series. Journal of the American Statistical Association 79, 907-915.

Granger, C.W.J., 1969. Investigating causal relationships by econometric models and crossspectral methods. Econometrica 37, 424-438.

Olson, M., 1996. The varieties of Eurosclerosis: The rise and decline of nations since 1982. In: N. Crafts and G. Toniolo, eds., Economic growth in Europe since 1945 (Cambridge University Press, Cambridge), 73-94.

Paqué, K.-H., 1993. Germany: Living with tight corporatism. In: J. Hartog and J. Theeuwes, eds., Labour market contracts and institutions (North-Holland, Amsterdam), 209-32.

Phillips, P. and P. Perron, 1988. Testing for a unit root in time series regression. Biometrika 75, 335-346.

Sims, C.A., 1980. Macroeconomics and reality. Econometrica 48, 1-48.

Teulings, C. and J. Hartog., 1998. Corporatism or competition? (Cambridge University Press, Cambridge). 
Table 1

Disentangling Contractual Wages/Salaries and Productivity in

Western Germany, 1960-1998: Geweke Conditional Linear Feedback Measures ${ }^{a}$

Percent Reduction in the Prediction Error Variance of

Salary /Wage and Productivity Forecasts:

Adjusted Point Estimates (90-Percent Confidence Bands)

\begin{tabular}{|c|c|c|c|}
\hline \multicolumn{4}{|c|}{ Panel A: Wage earners } \\
\hline \multirow[t]{2}{*}{ Feedback Measures $^{b}$} & $F_{p r d^{*} \rightarrow w g^{*}} \mid u r^{*}$ & $F_{w g^{*} \rightarrow p r d^{*} \mid u r^{*}}$ & $F_{w g^{*} \cdot p r d^{*} \mid u r^{*}}$ \\
\hline & $\begin{array}{c}7.34 \\
(2.66,91.49)\end{array}$ & $\begin{array}{c}0.00 \\
(0.00,0.76)\end{array}$ & $\begin{array}{c}0.00 \\
(0.00,0.03)\end{array}$ \\
\hline \multicolumn{4}{|c|}{ Panel B: Salary earners } \\
\hline \multirow[t]{2}{*}{ Feedback Measures $^{b}$} & $F_{p r d^{*} \rightarrow s^{*} \mid u r^{*}}$ & $F_{s l^{*} \rightarrow p r d^{*} \mid u r} *$ & $F_{s l^{*} \cdot p r d^{*} \mid u r^{*}}$ \\
\hline & $\begin{array}{c}8.30 \\
(3.16,72.93)\end{array}$ & $\begin{array}{c}0.68 \\
(0.19,48.85)\end{array}$ & $\begin{array}{c}0.02 \\
(0.01,3.45)\end{array}$ \\
\hline
\end{tabular}

${ }^{a}$ For sources of the salary, wage, productivity, and unemployment data, see the appendix.

${ }^{\mathrm{b}}$ On conditional feedback from productivity to earnings, see equations (4-6). For conditional

feedback from earnings to productivity, see equations (1-3). On contemporaneous association

between earnings and productivity, see equations $(1,7-8)$. In all cases, $w g_{t}^{*} \equiv\left(w g_{t}-w g_{t-1}\right)$;

$s l_{t}^{*} \equiv\left(s l_{t}-s l_{t-1}\right) ; p r d_{t}^{*} \equiv\left(p r d_{t}-\operatorname{prd}_{t-1}\right) ; u r_{t}^{*} \equiv\left(u r_{t}-u r_{t-1}\right)$. 


\section{IZA Discussion Papers}

\begin{tabular}{|c|c|c|c|c|}
\hline No. & Author(s) & Title & Area & Date \\
\hline 582 & $\begin{array}{l}\text { P. Cahuc } \\
\text { C. Gianella } \\
\text { D. Goux } \\
\text { A. Zylberberg }\end{array}$ & $\begin{array}{l}\text { Equalizing Wage Differences and Bargaining } \\
\text { Power: Evidence from a Panel of French Firms }\end{array}$ & 6 & $09 / 02$ \\
\hline 583 & $\begin{array}{l}\text { P. Cahuc } \\
\text { F. Fontaine }\end{array}$ & $\begin{array}{l}\text { On the Efficiency of Job Search with Social } \\
\text { Networks }\end{array}$ & 5 & $09 / 02$ \\
\hline 584 & $\begin{array}{l}\text { C. J. Heinrich } \\
\text { P. R. Mueser } \\
\text { K. R. Troske }\end{array}$ & $\begin{array}{l}\text { Welfare to Temporary Work: Implications for } \\
\text { Labor Market Outcomes }\end{array}$ & 3 & $09 / 02$ \\
\hline 585 & $\begin{array}{l}\text { M. Cervellati } \\
\text { U. Sunde }\end{array}$ & $\begin{array}{l}\text { Human Capital Formation, Life Expectancy and } \\
\text { the Process of Economic Development }\end{array}$ & 3 & $09 / 02$ \\
\hline 586 & $\begin{array}{l}\text { P. Díaz-Vázquez } \\
\text { D. Snower }\end{array}$ & $\begin{array}{l}\text { On-the Job Training and the Effects of Insider } \\
\text { Power }\end{array}$ & 3 & $09 / 02$ \\
\hline 587 & $\begin{array}{l}\text { H. Bonin } \\
\text { W. Kempe } \\
\text { H. Schneider }\end{array}$ & $\begin{array}{l}\text { Kombilohn oder Workfare? Zur Wirksamkeit } \\
\text { zweier arbeitsmarktpolitischer Strategien }\end{array}$ & 3 & $09 / 02$ \\
\hline 588 & M. Frölich & $\begin{array}{l}\text { Nonparametric IV Estimation of Local Average } \\
\text { Treatment Effects with Covariates }\end{array}$ & 6 & $09 / 02$ \\
\hline 589 & $\begin{array}{l}\text { S. Jurajda } \\
\text { K. Terrell }\end{array}$ & $\begin{array}{l}\text { Job Growth in Early Transition: Comparing Two } \\
\text { Paths }\end{array}$ & 4 & $09 / 02$ \\
\hline 590 & $\begin{array}{l}\text { H. Görg } \\
\text { E. Strobl } \\
\text { F. Walsh }\end{array}$ & $\begin{array}{l}\text { Why Do Foreign-Owned Firms Pay More? } \\
\text { The Role of On-the-Job Training }\end{array}$ & 2 & $10 / 02$ \\
\hline 591 & $\begin{array}{l}\text { H. Görg } \\
\text { E. Strobl }\end{array}$ & $\begin{array}{l}\text { Spillovers From Foreign Firms Through Worker } \\
\text { Mobility: An Empirical Investigation }\end{array}$ & 1 & $10 / 02$ \\
\hline 592 & J. Wagner & $\begin{array}{l}\text { Testing Lazear's Jack-of-All-Trades View of } \\
\text { Entrepreneurship with German Micro Data }\end{array}$ & 5 & $10 / 02$ \\
\hline 593 & $\begin{array}{l}\text { T. K. Bauer } \\
\text { P. J. Dross } \\
\text { J. P. Haisken-DeNew }\end{array}$ & Sheepskin Effects in Japan & 1 & $10 / 02$ \\
\hline 594 & $\begin{array}{l}\text { S. C. Wolter } \\
\text { M. Coradi Vellacott }\end{array}$ & $\begin{array}{l}\text { Sibling Rivalry: A Look at Switzerland with } \\
\text { PISA Data }\end{array}$ & 2 & $10 / 02$ \\
\hline 595 & $\begin{array}{l}\text { W. Arulampalam } \\
\text { A. L Booth } \\
\text { M. L. Bryan }\end{array}$ & $\begin{array}{l}\text { Work-Related Training and the New National } \\
\text { Minimum Wage in Britain }\end{array}$ & 3 & $10 / 02$ \\
\hline 596 & $\begin{array}{l}\text { H. Görg } \\
\text { E. Strobl }\end{array}$ & $\begin{array}{l}\text { Relative Wages, Openness and Skill-Biased } \\
\text { Technological Change }\end{array}$ & 2 & $10 / 02$ \\
\hline 597 & $\begin{array}{l}\text { S. M. Fuess, Jr. } \\
\text { M. Millea }\end{array}$ & $\begin{array}{l}\text { Disentangling Pay and Productivity in a } \\
\text { Corporatist Economy: The Case of Germany }\end{array}$ & 5 & $10 / 02$ \\
\hline
\end{tabular}

An updated list of IZA Discussion Papers is available on the center's homepage www.iza.org. 